\title{
Komentar terhadap makalah : KRISIS MONETER INDONESIA : SEBAB, DAMPAK, PERAN IMF DAN SARAN
}

\author{
Sjamsul Arifin *)
}

S

udah banyak studi dan analisis mengenai krisis moneter di Indonesia dilakukan oleh para peneliti baik dalam negeri maupun luar negeri. Berbeda dengan studi yang telah dilakukan oleh para peneliti lain, makalah yang ditulis oleh Prof. Dr. Lepi T. Tarmidi ini memuat analisis yang komprehensif dan kritis disertai saran-saran dalam mengatasi krisis. Diawali dengan latar belakang krisis, penulis secara obyektif dan seimbang mengemukakan berbagai kelebihan dan kekurangan dari program IMF sebagai program yang diharapkan akan mampu mengatasi krisis di Indonesia. Studi semacam ini sangat bermanfaat sebagai masukan bagi para pengambil keputusan karena bagaimanapun juga kalangan akademis pada umumnya bisa memberikan penilaian yang obyektif atas kebijakan yang diambil oleh para birokrat.

Penulis umumnya setuju dengan para pakar lainnya mengenai berbagai penyebab krisis, antara lain bahwa tekanan terhadap nilai rupiah pada awalnya dipicu oleh kegiatan spekulan asing yang menyebar dari Thailand (contagion effect). Kemudian, krisis makin mendalam akibat (a) kurangnya pengawasan yang memadai dalam sistem devisa yang bebas, poor governance dan kurangnya transparansi sehingga tanpa disadari telah terjadi akumulasi utang swasta luar negeri yang sangat besar dengan tenor jangka pendek dan cenderung tidak dilindung nilai, (b) lemahnya sistem perbankan nasional, (c) ketidakstabilan politik, dan (d) hilangnya kepercayaan masyarakat dalam dan luar negeri akan kemampuan pemerintah dalam memulihkan perekonomian.

Program IMF yang menurut analisis penulis tepat untuk mengatasi krisis meliputi kebijakan moneter ketat dalam rangka stabilisasi nilai tukar, restrukturisasi sektor perbankan dan beberapa reformasi struktural dalam rangka meningkatkan efisiensi sektor riil seperti penghentian pembebasan pajak dan kemudahan kredituntuk proyek mobil nasional dan IPTN.

Menurut penulis, pola pencairan dana bantuannya kepada Indonesia yang dilakukan secara bertahap dalam jangka waktu yang cukup jauh menunjukkan bahwa IMF terlalu menekan Indonesia dan terkesan membiarkan ekonomi Indonesia merosot menuju resesi yang berkepanjangan. Dalam anggaran dasar IMF, memang disebutkan bahwa pemberian pinjaman kepada IMF memang selalu disertai dengan adanya sejumlah persyaratan

1 Sjamsul Arifin : Deputi Kepala Urusan Riset Ekonomi dan Kebijakan Moneter, Bank Indonesia 
(conditionality). Semakin besar jumlah pinjaman (biasanya dikaitkan dengan besarnya kuota negara yang bersangkutan), semakin banyak persyaratan yang harus dilaksanakan. Tujuan dari persyaratan tersebut, termasuk pencairan yang dilaksanakan secara bertahap, adalah untuk menjamin agar negara peminjam melaksanakan program yang telah ditetapkan secara konsisten sehingga diharapkan perekonomian akan pulih kembali dan dengan demikian peminjam akan mampu mengambalikan utangnya. Pada umumnya review atas program stand-by arrangement dilaksanakan sekali dalam tiga bulan. Namun dalam program stand-by arrangement untuk Indonesia review dilaksanakan sebulan sekali. Hal ini memang mencerminkan sikap IMF terhadap Indonesia yang cenderung lebih berhati-hati. Namun setelah kepercayaan IMF terhadap komitmen pemerintah dalam melaksanakan program stabilisasi dan reformasi meningkat, frekuensi review dikurangi menjadi sekali dalam duabulan.

Beberapakekurangan program IMF antara lain meliputi (a) kurang memperhitungkan dampak psikologis dari tindakan penutupan bank domestik yang di lakukan atas sarannya pada saat belum adanya program penjaminan bank oleh pemerintah, (b) terlalu menekan pemerintah Indonesia untuk melaksanakan reformasi struktural secara besar-besaran (c) tidak bersedia membantu penyelesaian utang swasta karena keengganan untuk bail-out utang sektor swasta karena dikhawatirkan akan terjadi moral hazard. Kekurangankekurangan tersebut selanjutnya memang diakui sendiri oleh IMF seperti tertulis dalam beberapa publikasinya dan menyetujui anggaran pemerintah yang defisit untuk menstimulir kegiatan ekonomi. IMF selanjutnya juga bersedia membantu menyelesaikan utang sektor swasta sehingga tercapai kesepakatan Frankfut.

Selain itu, penulisjuga secaratajam menyampaikan kritik atas saran-saran IM F yang dianggap kurang tepat untuk diterapkan pemerintah. Hal-hal tersebut meliputi liberalisasi yang harus dilakukan pemerintah seperti pemberian keleluasaan yang sangat besar bagi pihak asing untuk memiliki atau mendirikan badan usaha yang $100 \%$ dimiliki asing. Memang sangat beralasan bagi penulis untuk menyatakan kegusarannya dengan liberalisasi tersebut. Tetapi sebagian dari langkah tersebut mungkin memang bukan pilihan terbaik (first best), melainkan terbaik diantara yang jelek. Sebagai contoh, apabila pihak asing tidak diperkenankan untuk membeli bank yang tidak mampu menyetor modal maka pilihannya ialah: kerugian ditanggung nasabah dan pemilik, pemerintah atau bank ditutup. A pabila setoran modal ditanggung Pemerintah, maka Pemerintah membiayainya dengan penerbitan obligasi. Semakin besar dana yang dibutuhkan, maka obligasi yang diterbitkan juga menjadi lebih banyak. Mengingat biaya obligasi yang dibayar pemerintah adalah berasal dari APBN yang didanai pajak, berarti hal ini akan semakin memberatkan rakyat.

Kami setuju dengan pendapat penulis bahwa saran IMF untuk membuka kesempatan yang lebih besar kepada pihak asing mengakibatkan liberalisasi menjadi jauh melebihi komitmen resmi pemerintah padaWTO, AFTA, dan A PEC. Bahkan negara-negara anggota 
WTO juga mengakui hal ini seperti yang mereka nyatakan dalam sidang TradePolicy Review Mechanism (TPRM) untuk Indonesia di Jenewa bulan Desember 1998 yang memberikan komentar bahwa menjelang milenium keduaini, Indonesia merupakan negara berkembang yang paling terbuka di dunia. Namun demikian hal ini tidak dengan sendirinya berarti bahwa Indonesia terikat dengan liberalisasi yang dilakukan terhadap lembaga-lembaga tersebut. Hal ini disebabkan liberalisasi yang dilakukan pemerintah bersifat unilateral dalam rangka pelaksanaan program stabilisasi dan reformasi yang didukung IMF. Dalam hal ini, pemerintah memang wajib melaksanakan program tersebut karena sudah merupakan conditionality dari IMF. Namun hal ini tidak berarti bahwa hal ini merupakan komitmen terhadap lembaga lain, seperti WTO. Komitmen terhadap WTO dilakukan setelah melalui proses negosiasi offer dan request. Dengan demikian, pemerintah juga berhak untuk tidak mengikat liberalisasi tersebut dalam perjanjian WTO dengan berbagai alasan tergantung dari kemampuan dan kepentingan kita dalam bernegoisiasi. Dalam hal ini, salah satu faktor penting yang mutlak harus dimi liki negosiator adalah berbagai ketentuan, terutama hambatan yang diterapkan oleh negara lain yang bernegosiasi dengan kita.

Liberal isasi yang dilakukan pemerintah juga tidak berarti bahwa Pemerintah tidak menyisakan bidang kegiatan untuk pengusaha Indonesia, terutama yang bermodal kecil sebagaimana yang dikemukakan penulis. Sebagaimana kita ketahui, pihak asing selalu berupaya untuk memperoleh keuntungan dari usahanya di sini. Tetapi tidak semua bidang usaha menguntungkan bagi pihak asing, karena merekamempunyai segmen pasar tersendiri. Di bidang perbankan, misalnya walaupun pihak asing sudah berada di Indoseia selama puluhan tahun, tidak berarti bahwa semua perbankan langsung dikuasai bank asing. Sejak tahun 1992 sampai tahun 1996 pangsa usaha mereka tidak banyak berubah, yaitu sekitar 6.5\%. Pangsa bank asing meningkat menjadi sekitar 10\% sejak terjadinya krisis 1997. Selain itu, keberadaan mereka juga mendukung keberadaan PMA. Sebagai contoh, PMA jepang pada umumnya lebih sengan untuk menggunakan jasa bank yang berasal dari Jepang karena lebih mudah mendukung kegiatan usahanya, termasuk dalammemanfaatkan berbagai jasa perbankan, misalnya dalam hal transfer dan informasi perkembangan perekonoian dan usaha di Jepang. A pabila kita memiliki kekhawatiran, sebetulnya kita bisa menerapkan persyaratan adanya opsi untuk membeli kembali bank-bank yang dijual kepada pihak asing. Dengan demikian, setelah perekonomian kita pulih kembali dan pemiliki modal memiliki dana yang cukup maka saham pihak asing dapat dibeli kembali.

Mengenai saran penulis untuk mempertahankan nilai tukar rupiah yang sedikit undervalued, hal ini memang ada kelebihan dan kekurangannya. Nilai tukar yang undervalued memang dapat memberi keuntungan karena dayasaing produsen dal am negeri meningkat sehingga ekspor bertambah dan impor berkurang. Dalam hal ini sebetulnya yang lebih relevan adalah membicarakan daya saing itu sendiri. Daya saing memang 
dipengaruhi oleh dua faktor utama, yaitu efisiensi dan harga. A pabila kita dapat meningkatkan efisiensi misal nya melalui produktivitas yang tinggi maka produk kita akan menjadi kompetitif di pasar luar negeri.

Daya saing juga dapat meningkat apabila kita dapat menawarkan produk dengan hargayang lebih rendah. A da dua cara yang dapat dilakukan produsen untuk memperoleh keuntungan. Pertama dengan menghilangkan ekonomi biaya tinggi melalui penghapusan berbagai distorsi, terutama untuk bahan baku yang diperlukan dalam proses produksi. Hal ini dapat dilakukan melalui liberalisasi atau deregulasi di sektor riil yang sekarang sedang dilaksanakan pemerintah. Cara kedua adalah melalui depresiasi. Di antara kedua cara tersebut, cara pertama mempunyai keunggulan daripada cara kedua. Hal ini disebabkan depresiasi pada tahap pertama memang dapat memberi keuntungan kepada produsen. Namun pada tahap berikutnya, depresiasi tidak akan mempunyai arti lagi karena insentifnya telah tererosi oleh inflasi yang ditimbulkan oleh depresiasi itu sendiri (depreciation-induced inflation). Untuk mempertahankan insentif tersebut, pada periodeberikutnya bank sentral harusmelakukan depresiasi lagi dan dengan demikian akan terjadi depreciation-inflation spiral.

Terakhir sebagai catatan kecil, mengenai jumlah kuota Indonesia di IMF sebesar \$ 2,07 miliar tidak semuanya dalam bentuk valas, melainkan hanya $25 \%$ dari jumlah tersebut yang berupa val as sedangkan $75 \%$ disetor dalam bentuk mata uang negara anggota (dalam hal ini rupiah) karena dalam Anggaran Dasar IMF pasal 3 memang demikian ketentuannya. 